\title{
Biochemical changes in alternative poultry meat during refrigerated storage
}

\section{Alterações bioquímicas em carne de aves alternativas durante o armazenamento em refrigeração}

\author{
César Aquiles Lázaro de la Torre, ${ }^{*}$ Carlos Adam Conte-Júnior, ${ }^{* *}$ Anna Carolina Vilhena da Cruz Silva Canto, ${ }^{*}$ Maria Lucia \\ Guerra Monteiro, ${ }^{*}$ Bruno Reis Carneiro da Costa Lima, ${ }^{*}$ Eliane Teixeira Mársico, ${ }^{* *}$ Sergio Borges Mano, ${ }^{* *}$ Robson Maia Franco ${ }^{* *}$
}

\begin{abstract}
The aim of this study was evaluated the physical and chemical changes in five types of alternative poultry meat keep at refrigerated conditions $\left(4 \pm 1^{\circ} \mathrm{C}\right)$ during 18 days. For this purpose, breast meat of conventional, organic and free-range chicken, duck and quail were purchase from markets of Niteroi city (Rio de Janeiro, Brazil). Levels of $\mathrm{pH}$, thiobarbituric acid reactive substances (TBARS) and biogenic amines (cadaverine and putrescine) were determinate. Statistic evaluation was performed using analyze of variance and Tukey test. The results showed a gradual and proportional increment of $\mathrm{pH}$ values (between 5.5 and 6.5 ) in all poultry meats during the storage time; an increment of TBARS values in the first days of storage, remaining stables to the end of experiment. A significant increment of putrescine values was observed after the sixth day remaining stable in conventional chicken and quail until the end of experiment while significant reduction was observed in the rest of poultry meats. Finally, only conventional and organic chicken and quail showed a gradual increment during storage time. In conclusion, significant biochemical changes was observed during the storage time being that $\mathrm{pH}$, cadaverine and putrescine values could be parameters using like deterioration indicators for these products.
\end{abstract}

Keywords: biogenic amines, chicken, duck, pH, quail, quality, TBARS.

\begin{abstract}
Resumo
O objetivo do presente estudo foi avaliar as mudanças físico-químicas de cinco tipos de carnes de aves alternativas mantidas em condições de refrigeração $\left(4 \pm 1^{\circ} \mathrm{C}\right)$ durante 18 dias. Para essa finalidade utilizou-se carne de peito de frangos convencional, caipira e orgânico, pato e codorna adquiridos de supermercados na cidade de Niterói (Rio de Janeiro, Brasil) e determinaramse os níveis de pH, substâncias reativas ao ácido tiobarbitúrico (SRATB) e aminas biogênicas (cadaverina e putrescina). Os resultados indicaram um incremento gradativo e proporcional dos valores de $\mathrm{pH}$ (entre 5,5 e 6,5) nas carnes de aves durante o tempo de estocagem; um aumento dos valores de SRATB nos primeiros dias de estocagem, mantendo-se invariáveis até o final do experimento. Em todas as aves foi observado um incremento significativo dos valores de putrescina após o sexto dia, mantendo-se estáveis no frango convencional e a codorna até o final do experimento, enquanto o resto das carnes diminuiu significativamente. Finalmente, foi observado um incremento gradativo apenas na codorna e nos frangos convencional e orgânico. Conclui-se que houve mudanças bioquímicas significativas nas carnes avaliadas durante o tempo de estocagem, sendo que os valores de $\mathrm{pH}$, cadaverina e putrescina seriam parâmetros que podem ser utilizados como indicadores de deterioração destes produtos.
\end{abstract}

Palavras-chave: aminas biogênicas, codorna, frango, pato, $\mathrm{pH}$, qualidade, TBARS.

\section{Introduction}

The Brazilian poultry industry sector of the contemporaneous economy has undergone profound changes over the past 40 years, presenting a set of changes related to the organizational structure encompassing much of the production processes, administrative and work organization (Buzanello and Moro, 2012). Due to the increase global consumption of alternative meats, the poultry industry constantly searches different options to attend consumer demands. In Brazil, the alternative poultry production system was initially implemented by small and medium producers as an opportunity to offer differentiated products of higher quality providing producers higher income through added value in relation to intensive production system. However, in recent years the alternative production is widely implemented in the poultry industry (Santos et al., 2012).

The Brazilian free-range chicken system is regulated by the Brazilian legislation; according to that, the chicken named freerange is fed exclusively with plant origin ration and the use of

\footnotetext{
* Postgraduate Program in Veterinary Medicine, Universidade Federal Fluminense, Vital Brazil Filho 64, CEP 24230-340, Niterói, Rio de Janeiro, Brazil.

** Department of Food Technology, Faculty of Veterinary, Universidade Federal Fluminense, Vital Brazil Filho 64, CEP 24230-340, Niterói, Rio de Janeiro, Brazil.

Corresponding author: César Aquiles Lázaro de la Torre Phone: +55(21)75266716, e-mail: aquil18@yahoo.com
} 
growth promoters is prohibited. Also, is recommended that the birds are reared in extensive and three square meters of pasture per animal and the slaughter takes place at the minimum age of 85 days (Brasil, 1999).

An increasing number of consumers demanding healthier and naturally grown foods have favored organic live-stock farming, which is reputed to be environmentally friendly, allied with promotion of animals good health, with high welfare standards results in high quality products (Castellini et al., 2002)

The aim of this study was determinate the biochemical changes in alternative poultry meats and evaluated if these biochemical parameters could be used as indicators of poultry meat deterioration.

\section{Materials and methods}

The present study evaluated the changes of $\mathrm{pH}$, thiobarbituric acid reactive substances and biogenic amines (cadaverine and putrescine) in five types of poultry meat keep at refrigerated $\left(4 \pm 1^{\circ} \mathrm{C}\right)$ conditions for 18 days.

Ten breast meat (m. Pectoralis maior) from conventional, ten from free-range and ten from organic chicken (Gallus gallus domesticus) were used. Furthermore, ten breast from duck (Anas platyrhynchos domesticus) and twenty from quail (Coturnix coturnix) were used. All samples were purchased from local markets in Niteroi city (Rio de Janeiro, Brazil). Frozen samples were thawed overnight at $4 \pm 1^{\circ} \mathrm{C}$ and were aseptically cut into pieces of $100 \mathrm{~g}$, placed in plastic bags for refrigerated storage at $4 \pm 1^{\circ} \mathrm{C}$ for 18 days. In case of quail an entire breast of each carcass was used. Biochemical changes were evaluated every two days during 18 days on refrigeration storage.

All reagents used in the present study were of analytical grade. Cadaverine and putrescine standards (Sigma Aldrich, St. Louis, MO, USA) and 2-thiobarbituric acid (4,6-dihydroxy2-mercaptopyrimidine) (Spectrum Chemical Mfg. Corp. New Jersey, USA) were purchased. Stock solution with $40 \mu \mathrm{g}$ of cadaverine and putrescine were prepared in $0.1 \mathrm{~N} \mathrm{HCl}$ and stored at $4 \pm 1^{\circ} \mathrm{C}$. Different dilutions were performed and used for the calibration curve.

The progress of oxidation was determined by the thiobarbituric acid reactive substances (TBARS) test according to Tarladgis et al. (1960). In brief, $10 \mathrm{~g}$ of sample were manually minced, homogenized with $97.5 \mathrm{~mL}$ of distilled water and transferred to a distillation tube which was added $2.5 \mathrm{~mL}$ of $\mathrm{HCl}(4 N)$. This sample was then distilled and the first $50 \mathrm{~mL}$ of distillate was collected. Next, $5 \mathrm{~mL}$ of the distillate were added to $5 \mathrm{~mL}$ of $0.02 \mathrm{M}$ thiobarbituric acid and were heated in a boiling water bath $\left(100^{\circ} \mathrm{C}\right)$ for $35 \mathrm{~min}$ for accelerate the reaction and, consequently, color development. The samples were immediately cooled with water and the absorbance was measured at $528 \mathrm{~nm}$ on a Smartspec Plus spectrophotometer (BioRad, Hercules, CA, USA). The final values were expressed as milligram of malondialdehyde (MDA) per kilogram. The $\mathrm{pH}$ values were performed by using a digital $\mathrm{pH}$ meter (Digimed $\circledast$ DM-22) equipped with a electrode (Digimed $\circledast$ ) DME-R12) after briefly homogenization of $10 \mathrm{~g}$ of muscle sample with $90 \mathrm{~mL}$ of distilled water (Conte-Júnior et al., 2008).

Biogenic amines determination was performed in accordance with a modified procedure proposed by Conte Junior et al. (2006). Extraction were carried out using $5 \mathrm{~g}$ of meat and $5 \mathrm{~mL}$ of $5 \%$ perchloryc acid; the mixture was homogenized (Certomat $\AA \mathrm{MV}$,
B. Braun Biotech International) for 30 seconds in ten minutes intervals up to one hour; the sample tubes were kept under refrigeration $\left(4 \pm 2^{\circ} \mathrm{C}\right)$ during the whole process. The homogenate was centrifuged at $503 \mathrm{~g}$ for $10 \mathrm{~min}$ at $4 \pm 1^{\circ} \mathrm{C}$ (Hermle Z $360 \mathrm{~K}$ ) and filtered with Whatman No. 1 paper. The filtrates were neutralized $(\mathrm{pH}>6)$ with $2 \mathrm{~N} \mathrm{NaOH}$ and kept in ice bath $\left(0 \pm 1^{\circ} \mathrm{C}\right)$ for $20 \mathrm{~min}$. A second filtration and alkalynization with $\mathrm{NaOH}(\mathrm{pH}>12)$ were performed in the same conditions.

The derivatization was performance with addition of $40 \mathrm{~mL}$ benzoyl chloride, followed by homogenization in vortex for $15 \mathrm{sec}$ and kept at room temperature $\left(25 \pm 2^{\circ} \mathrm{C}\right)$ for $20 \mathrm{~min}$. The biogenic amines were collected through liquid partitioning with $1000 \mathrm{~mL}$ of diethyl ether, which was proceeded in two times. The ether layers containing amines were evaporated to dryness under nitrogen stream (Sample Concentrator Techne, Cambridge, UK). Finally, the residue was dissolved in $1000 \mathrm{~mL}$ of mobile phase (acetonitrile:water) and stored at $4 \pm 1^{\circ} \mathrm{C}$.

The chromatographic system consisted of a Shimadzu LC/10AS liquid chromatography coupled to SPD/10AV UV-Vis detector and C-R6A Chromatopack integrator. Amines separation were performed on Teknokroma Tracer Extrasil ODS2 (15 x 0.46cm id., $5 \mu \mathrm{m}$ ) column equipped with a Supelco, Ascentis C18 (2 $x 0.40 \mathrm{~cm}$, id. $5 \mu \mathrm{m})$ guard column, in isocratic condition. The mobile phase was prepared by mixing acetonitrile (Tediaß) with ultrapure water purified on Millipore Simplicity (Millipore, Molsheim, France) at 42:58 (v/v); and degassed in ultrasonic bath (Cleaner USC $2800 \mathrm{~A}$ ). The chromatography conditions were: flow rate of $1 \mathrm{~mL} \cdot \mathrm{min}^{-1}$, injection volume of $20 \mu \mathrm{L}$, column temperature of $20^{\circ} \mathrm{C}$ and detector wavelength set at $198 \mathrm{~nm}$. Injection was performed using a $50 \mu \mathrm{L}$ syringe (Hamilton TM 705) and total run time of 15 minutes. Injection of pure acetonitrile for 10 min was used between each sample for conditioning the HPLC system. Presence of biogenic amines were identified by retention time and quantified by peak area.

A two-way analysis of variance with repeated measures on two factors was used to identify differences in $\mathrm{pH}$, TBARS and biogenic amines content in different poultry meat. When a significant $F$ was found, additional post hoc tests with Tukey adjustment were performed. For the interpretation, data set was divided, for all above-mentioned analyses, in four periods: Period 0 (P0) - analysis of day 0 of storage; Period 1 (P1) analysis of the first six days of storage; Period $2(P 2)-$ analysis of the subsequent six days; and Period 3 (P3) - analysis of the last six days of storage. Statistical significance was set at the 0.05 level of confidence. All analyses were performed using a commercially available statistical package Graphpad (2007) Prism version. 5.00 for Windows (GraphPad Software, San Diego California USA).

\section{Results and discussion}

At the beginning of the experiment quail, duck, free-range and conventional chicken had similar values between 5.57 and 5.77. On the other hand, organic chicken showed values of $\mathrm{pH}$ above of 6.0. Through all of storage period all meats showed a significant increase demonstrating that $\mathrm{pH}$ can be considered a quality parameter (Figure 1). These results are similar to those found by Castellini et al. (2002) that determined $\mathrm{pH}$ values of 5.75 and 5.80 for organic chickens slaughtered at 56 and 81 days of age respectively; these values would be related to the rearing system of those birds in open environments and better 
welfare conditions which would reduce the stress pre-slaughter and further consumption of muscle glycogen. Free-range chicken had acidic values which are consistent with the results of Cheng et al. (2008) and Faria et al. (2009) who observed pH values between 5.70 and 5.90 after $24 \mathrm{~h}$ post mortem in free-range chicken, explaining that larger diameter muscle fibers was related to slow-growing chicken, which have higher glycolytic activity and reduced glycogen reserves before slaughter, fact that determine the final $\mathrm{pH}$ observed.

All poultry meats showed lower initial levels of TBARS $(0.10$ $\left.0.25 \mathrm{mg}^{\mathrm{kg}} \mathrm{k}^{-1}\right)$. Conventional and free-range chicken meat showed no difference during storage time (Figure 2). On the other hands, organic chicken, duck and quail showed a significant increase in the first six days of storage and then these values remained stable until the end of the storage period; this fact suggest that a early increment of MDA in these birds indicate an early stage of rancidity, which would not be suitable as quality indicator like $\mathrm{pH}$ values. The quail showed highest values (above of $1 \mathrm{mg}^{\mathrm{kg}}{ }^{-1}$ ) compared to other birds; these results can be explained because the quail were purchased with the skin that may have contributed to the increase of oxidative rancidity, while all chicken breasts were acquired without skin.

Our results were similar to reported by Alasnier et al. (2000) who determined low initial levels of lipid oxidation $0.03 \mathrm{mg} \cdot \mathrm{kg}^{-1}$ followed by a linear increment until $0.30 \mathrm{mg} \cdot \mathrm{kg}^{-1}$ at day 14 in chicken breast meat; these authors suggested that lower ratios of vitamin $E$ in chicken meat prevents the oxidation of long-chain PUFAs in the initials days and after the antioxidant reserves exhausted, the lipid oxidation is more evident. On the other hands, Castellini et al. (2002) and Castellini et al. (2006) evaluating the physical and chemical characteristics of organic chickens and found TBARS values above 2 mg. $\mathrm{kg}^{-1}, 24 \mathrm{~h}$ post mortem. They explained that the type of rearing of these birds, in open environments with intense muscle activity, could increase muscle oxidative metabolism and the production of free radicals. Husak et al. (2008) evaluated organic, free-range and conventional chickens, found TBARS values between 0.12 and $0.19 \mathrm{mg} \cdot \mathrm{kg}^{-1}$, not considered indicative of rancidity in any chicken.

Figure 2: Thiobarbituric acid reactive substances (TBARS) concentration in different poultry meats in refrigerated conditions $\left(4 \pm 1^{\circ} \mathrm{C}\right)$ storage during 18 days. The symbol * over the bars indicate significant differences between of periods storage in the same kind of poultry meat. Abbreviations: $C C=$ Conventional chicken, FRC $=$ Freerange chicken, $\mathrm{OC}=$ Organic chicken, $\mathrm{D}=$ Duck, $\mathrm{Q}=$ Quail, $\mathrm{PO}=\mathrm{Day} 0$ of storage; $\mathrm{P} 1=1-6$ days of storage, $\mathrm{P} 2=7-12$ days of storage, and P3 = $13-18$ days of storage 
Putrescine levels showed a gradually increase in conventional chicken and quail and after the first six days of storage it increased at significant levels. Similar behavior was observed in free-range chicken but the highest levels were detected between 7 and 12 day of storage, followed by a significant decrease in the last period of experiment. Organic chicken showed a slightly increment between 7 and 12 day of storage but it was not significant. Duck levels also started at low level and significantly increased between 2 and 12 day of storage; then it was observed a slightly decrease (Figure 3 ).
$4.3 \mathrm{mg} \mathrm{kg}^{-1}$ for putrescine and cadaverine respectively in chicken meat storage at $4^{\circ} \mathrm{C}$ for 15 days; similar results were obtained by Rokka et al. (2004) for both amines in chicken meat storage at different temperatures between 2 and $8{ }^{\circ} \mathrm{C}$; finally Balamatsia et al. (2007) who showed a linear increase from 53.8 to 409.6 $\mathrm{mg} \cdot \mathrm{kg}^{-1}$ and 19.8 to $252.8 \mathrm{mg} \cdot \mathrm{kg}^{-1}$ for putrescine and cadaverine, respectively, in chicken meat storage at $4^{\circ} \mathrm{C}$ for 17 days. On the other hand, ours results of putrescine for duck meat were different to Dadáková et al. (2012) who determined values of $3.2 \mathrm{mg} \cdot \mathrm{kg}^{-1}$ which slightly declined in the first week.

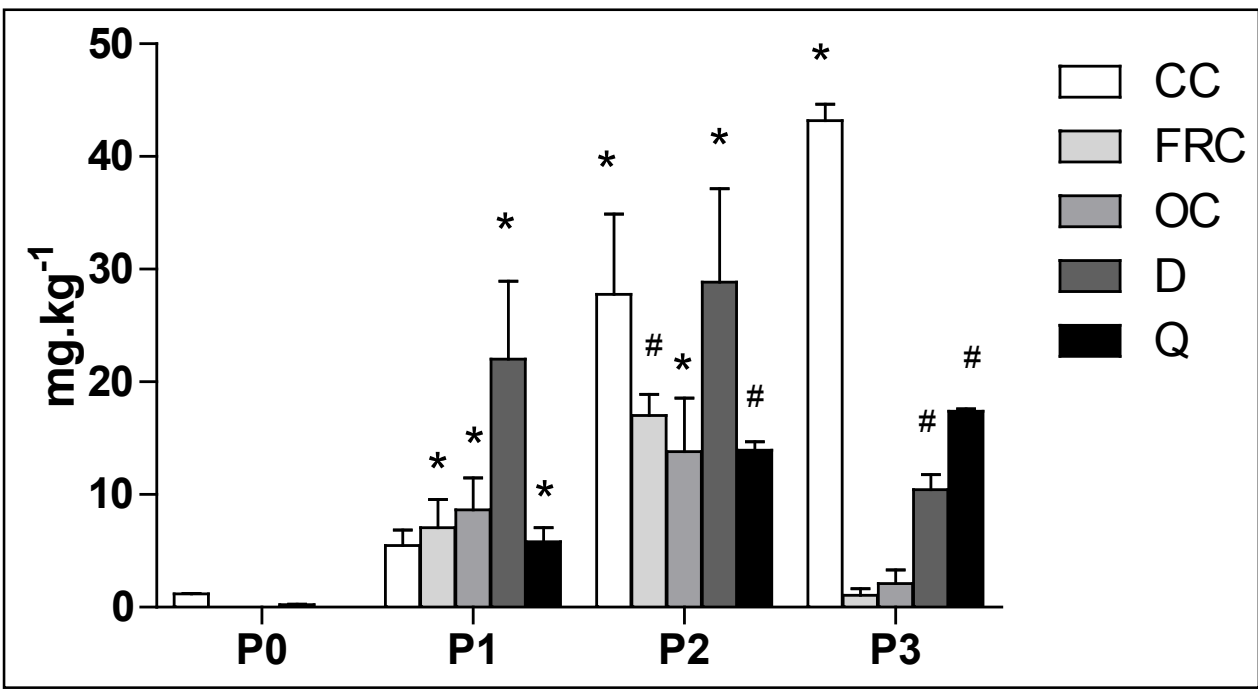

Figure 3: Putrescine concentration in different poultry meats in refrigerated conditions $\left(4 \pm 1^{\circ} \mathrm{C}\right)$ storage during 18 days. The symbols $\left.{ }^{*, \#}\right)$ over the bars indicate significant differences between of periods storage in the same kind of poultry meat. Abbreviations: $\mathrm{CC}=$ Conventional chicken, $\mathrm{FRC}=$ Free-range chicken, $\mathrm{OC}=$ Organic chicken, $\mathrm{D}=$ Duck, $\mathrm{Q}=$ Quail, $\mathrm{P} 0=$ Day 0 of storage; $\mathrm{P} 1=1-6$ days of storage, $\mathrm{P} 2=7-12$ days of storage, and $\mathrm{P} 3=13-18$ days of storage

Regarding, cadaverine it was observed that only organic meat showed detectable values at day 0 . Conventional chicken showed the lowest values until the 12 day of storage when significantly increased. Freerange progressively increased until 12 day, after that a significantly decrease was observed. Organic chickens and quail showed a gradually and significantly increase in all periods of storage. Duck values slightly increased in the first and then remain stables to the end of period storage (Figure 4).

Putrescine and cadaverine values were rather low in comparison to the levels reported by Sander et al. (1996), who found 200 and 500 $\mathrm{mg} . \mathrm{kg}^{-1}$ respectively in chicken carcass $24 \mathrm{~h}$ post mortem. On the other hand, different authors described a gradually increase for those amines during storage. Silva and Gloria (2002) found 20.4 and storage, and $\mathrm{P} 3=13-18$ days of storage
Vinci and Antonelli (2002) comparing biogenic amines, including putrescine and cadaverine, in beef and chicken stored at $4 \pm 1^{\circ} \mathrm{C}$, reported that amines in white meat increases earlier than in red meat; they explained that it is due to shorter fibers in chicken than beef, which can be easily attacked by proteolytic enzymes, resulting in the increased availability of amino acid precursors of biogenic amines. Tamim and Doerr (2003) determinated that levels of putrescine depends on the presence of ornithine, which in turn is produced from arginine degradation; consequently their formation may be ruled by arginine-utilizing microorganisms that produce ornithine as the substrate of decarboxylation. The putrescine levels reduction in duck, free-range and organic

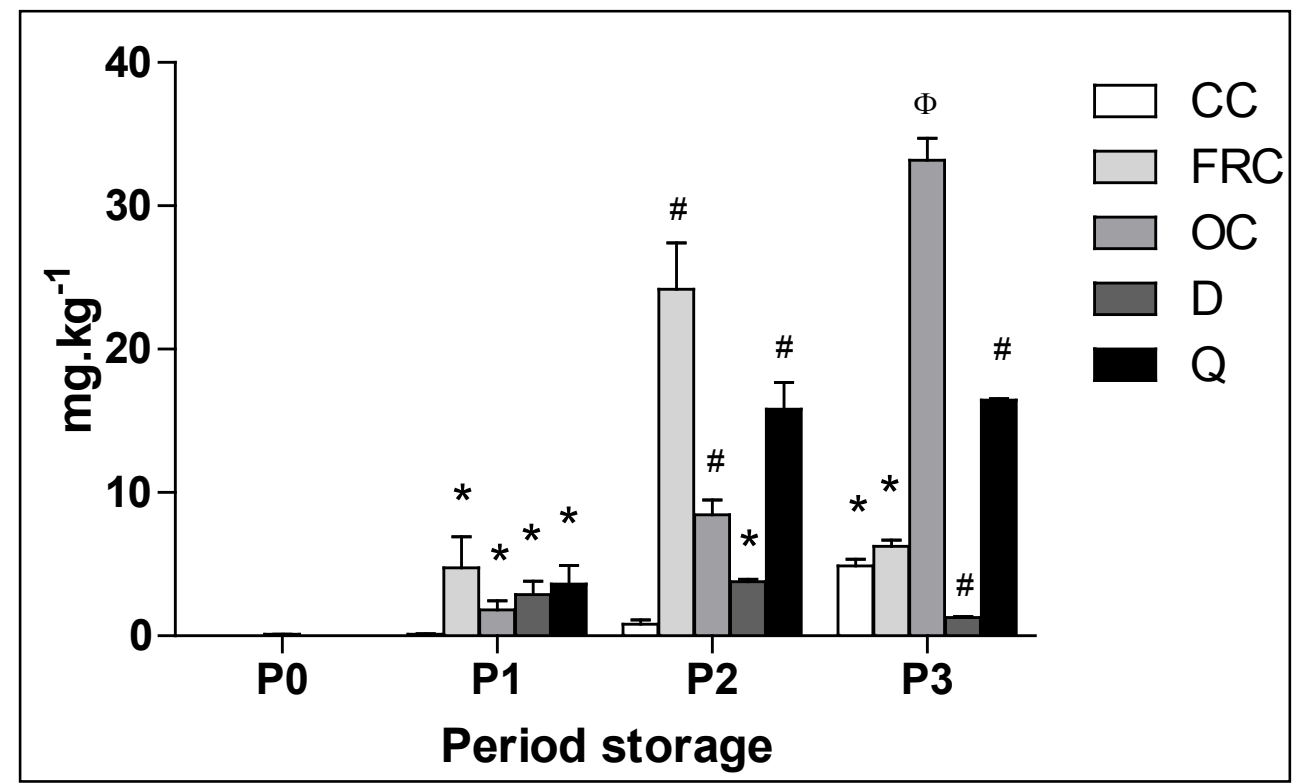

Figure 4: Cadaverine concentration in different poultry meats in refrigerated conditions $\left(4 \pm 1{ }^{\circ} \mathrm{C}\right)$ storage during 18 days. The symbols ${ }^{*}, \phi$, \# over the bars indicate significant differences between of periods storage in the same kind of poultry meat. Abbreviations: $\mathrm{CC}=$ Conventional chicken, $\mathrm{FRC}=$ Free-range chicken, $\mathrm{OC}=$ Organic chicken, $\mathrm{D}=$ Duck, $\mathrm{Q}=$ Quail, $\mathrm{P} 0=$ Day 0 of storage; $\mathrm{P} 1=1-6$ days of storage, $\mathrm{P} 2=7-12$ days of 
chicken in the latter period of storage can be related to the small amount of arginine. This condition is principally related to feeding and management. Khajali and Wideman (2010) indicated that reserves of arginine are consumed during stressful conditions in conventional chickens. The requirements of this amino acid and standard management are well-known in conventional chicken but a little information is available in other birds. The same assumption can be used with the requirements of lysine and cadaverine production.

The bacterial spoilage is another factor related with the putrescine and cadaverine production in meat products. In this case, although bacterial load was not evaluated, has been reported that variations in cadaverine levels could be due to differences in the capacity of the microorganisms, species and strain to produce cadaverine (Delgado-Pando et al., 2012).

Our results are important because these biochemical parameters could be useful and easily implemented by poultry industry as a possible indicator of poultry meat quality. According to Balamatsia et al. (2007), the changes in levels of amines were suitable as potential indices of fresh chicken meat quality. However, the authors indicated that these results corresponded to samples from one poultry plant and their general application must be verified.

\section{Conclusion}

The evaluation of five poultry meat showed biochemical changes during the storage time. Values of $\mathrm{pH}$ and putrescine in all poultry and cadaverine in quail, organic and free-range chicken, had a significant increase and could serve as indicators of storage time after 12 days. TBARS did not seem to have relationship with the storage time because increase only took place in the first days. Further studies should be carried out to evaluated others biochemical indicators (e.g.: spemine, spermidine, histamine, tyramine) and the correlation with microbiological parameters.

\section{Acknowledgments}

The authors are thankful for the financial support of the Fundação Carlos Chagas Filho de Amparo à Pesquisa do Estado do Rio de Janeiro (FAPERJ), processes numbers E-26/110.406/2012 and E-26/111.933/2011. The authors C.A. Lázaro, A.C.V.C.S. Canto, B.R.C.Costa Lima were supported by the Coordenação de Aperfeiçoamento de Pessoal de Nível Superior (CAPES). The author M.L.G. Monteiro acknowledges the Conselho Nacional de Desenvolvimento Científico e Tecnológico (CNPq).

\section{References}

ALASNIER, C.; MEYNIER, A.; VIAU, M. et al. Hydrolytic and Oxidative Changes in the Lipids of Chicken Breast and Thigh Muscles During Refrigerated Storage. Journal of Food Science, v. 65, n. 1, p. 9-14, 2000.

BALAMATSIA, C. C.; PATSIAS, A.; KONTOMINAS, M. G. et al. Possible role of volatile amines as quality-indicating metabolites in modified atmosphere-packaged chicken fillets: Correlation with microbiological and sensory attributes. Food Chemistry, v. 104, n. 4, p. 1622-1628, 2007.

BRASIL. Ofício Circular No 7, DE 19 de maio de 1999. Registro do Produto "Frango Caipira ou Frango Colonial" ou "Frango Tipo ou Estilo Caipira" ou "Tipo ou Estilo Colonial". Diário Oficial da República Federativa do Brasil. Brasília, DF: Ministério da Agricultura e do Abastecimento 1999.

BUZANELLO, M. R.; MORO, A. R. P. Increased of Brazilian productivity in the slaughterhouse sector: a review. Work: A Journal of Prevention, Assessment and Rehabilitation, v. 41, n. 0, p. 54465448, 2012.

CASTELLINI, C.; DAL BOSCO, A.; MUGNAI, C. et al. Comparison of two chicken genotypes organically reared: oxidative stability and other qualitative traits of the meat. Italian Journal Animal Science, v. 5, p. 29-42, 2006.

CASTELLINI, C.; MUGNAI, C.; DAL BOSCO, A. Effect of organic production system on broiler carcass and meat quality. Meat Science, v. 60, n. 3, p. 219-225, 2002.

CONTE-JÚNIOR, C. A.; FERNÁNDEZ, M.; MANO, S. B. Use of Carbon Dioxide to Control the Microbial Spoilage of Bullfrog (Rana catesbeiana) Meat. In: (Ed.). Modern Multidisciplinary Applied Microbiology: Wiley-VCH Verlag $\mathrm{GmbH}$ \& Co. KGaA, 2008. p. 356-361.

CONTE JUNIOR, C. A.; HIERRO, E.; ALVAREZ, M. F. Estudio de la producción de poliaminas por bacterias comensales aisladas de leche humana. Congreso Español de Microbiología de Los Alimentos. OURENSE. Ourense, España: Sociedad Española de Microbiología: 75 p. 2006.
CHENG, F. Y.; HUANG, C. W.; WAN, T. C. et al. Effects of freerange farming on carcass and meat qualities of black-feathered Taiwan native chicken. Asian-Australasian Journal of Animal Sciences, v. 21, n. 8, p. 1201-1206, Aug 2008.

DADÁKOVÁ, E.; PELIKÁNOVÁ, T.; KALAČ, P. Contents of biologically active polyamines in duck meat and giblets after slaughter and their changes during meat storage and cooking. Food Research International, v. 48, n. 1, p. 28-33, 2012.

DELGADO-PANDO, G.; COFRADES, S.; RUIZ-CAPILLAS, C. et al. Enriched n-3 PUFA/konjac gel low-fat pork liver pâté: Lipid oxidation, microbiological properties and biogenic amine formation during chilling storage. Meat Science, v. 92, n. 4, p. 762-767, 2012.

FARIA, P. B.; BRESSAN, M. C.; SOUZA, X. R. D. et al. Composição proximal e qualidade da carne de frangos das linhagens Paraíso Pedrês e Pescoço Pelado. Revista Brasileira de Zootecnia, v. 38, p. 2455-2464, 2009.

GRAPHPAD. GraphPad Prisma Version 5.0 San Diego, CA, USA: GraphPad Software Inc 2007.

HUSAK, R. L.; SEBRANEK, J. G.; BREGENDAHL, K. A Survey of Commercially Available Broilers Marketed as Organic, FreeRange, and Conventional Broilers for Cooked Meat Yields, Meat Composition, and Relative Value. Poultry Science, v. 87, n. 11, p. 2367-2376, November 20082008.

KHAJALI, F.; WIDEMAN, R. F. Dietary arginine: metabolic, environmental, immunological and physiological interrelationships. World's Poultry Science Journal, v. 66, n. 4, p. 751-766, 2010.

ROKKA, M.; EEROLA, S.; SMOLANDER, M. et al. Monitoring of the quality of modified atmosphere packaged broiler chicken cuts stored in different temperature conditions: B. Biogenic amines as quality-indicating metabolites. Food Control, v. 15, n. 8, p. 601-607, 2004.

SANDER, J. E.; CAI, T.; DALE, N. et al. Development of Biogenic Amines During Fermentation of Poultry Carcasses. The Journal of Applied Poultry Research, v. 5, n. 2, p. 161-166, Summer, 1996 1996. 
SANTOS, E. L. B. D.; JUNIOR, G. D. N.; LEANDRO, J. B. Estudo de viabilização da produção alternativa de aves. Tékhne $\varepsilon$ Lógos, v. 3, n. 1, p. 1-15, 2012.

SILVA, C. M. G.; GLORIA, M. B. A. Bioactive amines in chicken breast and thigh after slaughter and during storage at $4+/-1$ oC and in chicken-based meat products. Food Chemistry, v. 78, n. 2, p. 241-248, 2002.
TARLADGIS, B.; WATTS, B.; YOUNATHAN, M. et al. A distillation method for the quantitative determination of malonaldehyde in rancid foods. Journal of the American Oil Chemists' Society, v. 37, n. 1, p. 44-48, 1960.

VINCI, G.; ANTONELLI, M. L. Biogenic amines: quality index of freshness in red and white meat. Food Control, v. 13, n. 8, p. 519524, Dec 2002. 